\title{
Use of the Pilodyn for Assessing Wood Properties in Standing Trees of Eucalyptus Clones ${ }^{1}$
}

\author{
Wu Shijun ${ }^{1}, \mathrm{Xu}$ Jianmin $^{1 *}$, Li Guangyou ${ }^{1}$, Risto Vuokko ${ }^{2}$, \\ Lu Zhaohua ${ }^{1}$, Li Baoqi ${ }^{1}$ and Wang Wei ${ }^{1}$ \\ ${ }^{1}$ Research Institute of Tropical Forestry, \\ Chinese Academy of Forestry, Guangdong Guangzhou \\ ${ }^{2}$ Guangxi StoraEnso Forestry Corporation Ltd., Nanning, Guangxi
}

China

\section{Introduction}

As one of the major timer production species in the world, eucalyptus is characterized as fast-growing, high-yielding, and well adapted to different flat and mountainous environments with extreme low temperature of $-5^{\circ} \mathrm{C}$ ((Qi 2007)). Most of eucalypts species are naturally distributed in the continental Australia of Oceania, and a few native to the Timor Island of Indonesia and Papua New Guinea (Qi 2007).Identification and selection of superior trees in forest management and breeding programs provide a means to improve the properties and value of future wood products (Knowles et al. 2004). In recent years, breeding objectives in tree improvement have moved from volume per hectare alone, to include also wood properties and their impact on industrial end products (Wei and Borralho 1997). Wood basic density is considered as one of the most important wood properties which has a major impact on the freight costs, chipping properties, pulp yield per unit mass of wood and paper quality (Pliura et al. 2007; Laurence et al 1999). Wood basic density generally shows a high heritability and responds well to genetic improvement. But the genetics of wood density has not been studied in great detail (Macdonald et al. 1997). Currently, published information on genetic variation in wood basic density in eucalyptus is limited with a few studies conducted in China (Kien et al. 2008; Lu 2000; Luo 2003).

Measurement of wood density is expensive and time consuming and also create varying degrees of damage to experimental materials, and that has restricted the number and accuracy of the studies published (Hansen 2000; Wei et al. 1997). However, pilodyn sampling is faster, cheaper, and not destructive, thus resulting in overall higher expected gains for selection of

\footnotetext{
${ }^{1}$ This study belongs to the project of National Eleventh Five-Year Science and Technology" Breeding of High yield and High Quality Fast-growing Wood Species of Eucalyptus" (2006BAD01A15-4)

Author: Wu Shijun (1984-- ) male, Shandong Weifang, Under Post-graduate Student,

wushijun0128@163.com

*Corresponding Author: Xu Jianmin Professor
} 
trees or culling of seedling seed orchards in comparison with the more destructive direct assessment of density (Greaves et al. 1996). Kube and Raymond (2002) reported that core sampling for basic density is assumed to cost $\$ 10.5$ per tree, which includes field collection and laboratory processing, whereas the cost of pilodyn measurements is assumed to be $\$ 1.5$ per tree.

The primary objective of this study is to test the effectiveness of pilodyn for evaluating wood basic density, modulus of elasticity $(\mathrm{MoE})$ and other traits of eucalyptus clones in standing trees. This information will be used to develop appropriate selection strategies for eucalyptus breeding programs in southern China.

\section{Materials and methods}

\subsection{Trial description}

The trial was established at Shankou town in Guangxi (21 $34^{\prime} \mathrm{N}, 112^{\circ} 42 \mathrm{E}, 29 \mathrm{~m}$ asl.), and is affected by the north tropical monsoon with annual mean temperature of $23^{\circ} \mathrm{C}$ and annual mean rainfall of $1589 \mathrm{~mm}$. The lateritic red earth was derived from sandstone and contains $0.15 \%$ of organic matter $(0-20 \mathrm{~cm})$. Previous vegetation was a plantation of Eucalyptus. Indigenous vegetation was found on site. 22 eucalyptus clones (table 1) were planted in April 2004. Field design was randomized complete blocks with 7 replications and 5-tree plot in a spacing of $4 \mathrm{~m} \times 2 \mathrm{~m}$. Measurements and increment cores were collected in December 2008, at which time the trial was aged 56 months.

\begin{tabular}{cccc}
\hline Clone number & Clone Identity. & Parental Combination & Style of Seedling \\
\hline 1 & GRDH32-26 & E.urophylla $\times$ E.grandis & Cuttings \\
2 & W5 & ABL $12 \times$ Unknown & Tissue culture \\
3 & GRDH32-29 & E.urophylla $\times$ E.grandis & Cuttings \\
4 & M1 & E.urophylla $\times$ E.grandis & Tissue culture \\
5 & GRDH32-28 & E.urophylla $\times$ E.grandis & Cuttings \\
6 & SH1 & Leizhou NO.1 $\times$ Unknown & Tissue culture \\
7 & GRDH33-9 & E.urophylla $\times$ E.grandis & Cuttings \\
8 & U6 & E.urophylla $\times$ E.tereticornis & Tissue culture \\
9 & GRDH32-25 & E.urophylla $\times$ E.grandis & Cuttings \\
10 & DH32-29 & E.urophylla $\times$ E.grandis & Tissue culture \\
11 & GRDH42-6 & E.grandis $\times$ E.urophylla & Cuttings \\
12 & RGD3 & E.urophylla $\times$ E.camaldulensis & Tissue culture \\
13 & DH196 & E.urophylla $\times$ E.grandis & Cuttings \\
14 & DH32-28 & E.urophylla $\times$ E.grandis & Tissue culture \\
15 & GRDH30-10 & E.urophylla $\times$ E.grandis & Cuttings \\
16 & TH9224 & E.urophylla $\times$ E.camaldulensis & Tissue culture \\
17 & GRDH33-27 & E.urophylla $\times$ E.grandis & Cuttings \\
18 & LH1 & E.urophylla $\times$ E.tereticornis & Tissue culture \\
19 & TH9224 & E.grandis $\times$ E.camaldulensis & Cuttings \\
20 & DH32-22 & E.urophylla $\times$ E.grandis & Tissue culture \\
21 & DH32-13 & E.urophylla $\times$ E.grandis & Tissue culture \\
22 & DH32-25 & E.urophylla $\times$ E.grandis & Tissue culture \\
\hline
\end{tabular}

Note: Male parents of U6, W5 and SH1 were not clear.

Table 1. Details of clones in the analysis 


\subsection{Assessments of wood properties}

\subsubsection{Pilodyn penetration}

The pilodyn wood tester is an instrument originally developed in Switzerland for determining the degree of soft rot in wooded telephone poles (Raymond et al. 1998; Hansen 2000). Pilodyn penetration (PP), an indirect method for determining wood basic density, has been effective in assessing large number of trees in eucalyptus (Wei et al. 1997; Kien et al. 2008; Macdonald et al. 1997; Raymond et al. 1998) and other species (Ishiguri et al. 2008; Pliura et al. 2006). PP was measured using a 6-J Forest pilodyn with $2.5 \mathrm{~mm}$ steel needle, by over the bark and removing a small section of bark (approximately $40 \mathrm{~mm} \times 20 \mathrm{~mm}$ ) at $1.3 \mathrm{~m}$ respectively and taking two pilodyn shots on each of four aspects (north, south west and east) from an average tree per plot. The pilodyn is attractive in that it is rapid, does not require the use of an increment borer (destructive sampling), and is, in principle, free of operator bias (Cown 1978; Hansen 2000). To avoid introducing additional sources of error, all clones were sampled by the same team of people, minimizing the potential for operator error (Raymond et al. 1998).

\subsubsection{Modulus of elasticity}

FAKOPP microsecond timer is able to measure acoustic velocity in standing trees, by timing the acoustic wave as it travels along the stem between points a known distance apart (Knowles et al. 2004; Chauhan et al. 2006). The results signals were engendered by start and stop transducers and recorded on an oscilloscope. Stress wave velocity (SWV) was then calculated by dividing the test span by the measurement stress wave transmission time (Wang et. al. 2000).

$$
\mathrm{SWV}=\mathrm{L} / \mathrm{t}
$$

Where $\mathrm{L}=1500 \mathrm{~mm}$ is the distance between two probes, $\mathrm{t}$ is the transmission time in microseconds $(\mu \mathrm{s})$.

The SWV is combined with density measurements to give an estimated of dynamic MoE (Knowles et. al., 2004).

$$
\mathrm{MoE}=\rho \omega^{2}
$$

Where MoE is the dynamic modulus of elasticity, $\rho$ is the average green density of the stem, $\omega$ is the SWV.

\subsubsection{Wood basic density}

Wood basic density was defined as oven-dry wood mass per unit volume of green wood, and was measured using the water displacement method (Kube and Raymond 2002; Tappi 1989). Five mm increment cores from pith to bark were extracted at a height of $1.3 \mathrm{~m}$ in the south-north orientation from an average tree per plot, immediately stored in plastic tubes with both ends sealed (Kien et al. 2008).Wood basic density was determined using the water displacement method, with two weights for every sample: weight of water displaced by immersion of wedge $\left(w_{1}\right)$ and oven dry weight $\left(w_{2}\right)($ Kien et al. 2008). Basic DEN was then calculated as: 


$$
\text { Basic DEN }(\mathrm{g} \bullet \mathrm{cm}-3)=\mathrm{w}_{2} / \mathrm{w}_{1}
$$

Wood basic density, outer wood basic density and heartwood basic density were tested respectively.

\subsection{Statistic analysis}

The SAS software package was used to analyze the variance of different Pilodyn penetration and the relationship between the Pilodyn penetration and wood density or MOE, respectively.

The mean by ramet at each clone of sampling was submitted to a variance and a covariance analysis according to the following linear model (Hansen et. al. 1997):

$$
y_{i j}=\mu+\alpha_{i}+\beta_{i}+\varepsilon_{i j}
$$

where $y_{i j}$ is the performance of ramet of $i^{\text {th }}$ clone within $j^{\text {th }}$ block, $\mu$ is the general mean, $a_{i}$ is the random effect of the $i^{\text {th }}$ clone, $\beta_{\mathrm{j}}$ is the random effect of the $j^{\text {th }}$ block, $\varepsilon_{\mathrm{ij}}$ is the random error.

\section{Results and discussion}

\subsection{Comparison between Pilodyn penetration and wood properties}

The mean values of Pilodyn penetration and wood properties of 22 clones are listed in Table 2. The mean value ranged from 9.44 to $15.41 \mathrm{~mm}$ for Pilodyn penetration, 0.3514 to 0.4913 g.cm $\mathrm{cm}^{-3}$ for wood basic density and 3.94 to $7.53 \mathrm{GPa}$ for MoE, which were smaller than previous studies on the same species (Knowles et al. 2004; Kien et al. 2008; Wei et al. 1997) as well as other species (Jacques 2004; Zhu et al. 2008; Zhu et al. 2009). The most suitable range of basic density for pulpwood in eucalyptus is 0.48 to $0.57 \mathrm{~g} \cdot \mathrm{cm}^{-3}$ and pulp yield decrease sharply when basic density falls below 0.4 exceeds 0.60 (Dean 1995; Ikemori et. al. 1986). There were considerably lower density values than those found in this study. Consequently, wood basic density should be improved substantially to about $0.55 \mathrm{~g} \cdot \mathrm{cm}^{-3}$, and this would benefit pulp production in southern China (Kien et al. 2008). Clones of M1, RGD3 and TH9224 had higher basic density and MoE, meanwhile, clones of DH32-28, GRDH42-6 and DH196 had lower basic density and MoE.

The variation coefficient of Pilodyn penetration over the bark was ranged from $9.15 \%$ to $11.83 \%$, whereas those measured by removing the bark was ranged from $13.40 \%$ to $14.45 \%$ (Table 3). One possible explanation could be that bark thickness and branch cluster frequency could affect this value. This agreed well with previously published results by Wei (1997) and Yin (2008).

The analysis of variance of pilodyn is presented in Table 4 . There were significant ( $1 \%$ level) differences between pilodyn penetration of different treatment, different directions and different clones, indicating that selection of clones for pilodyn would be effective.

The regression equations and phenotypic correlations between pilodyn penetration and wood properties are given in Table 5 and Table 6, respectively. Generally strongly negative correlations were found between pilodyn and wood properties, ranging from -0.433 to 0.755, slightly lower than previously published study (Wei et al. 1997; Chapola 1994). The possible explanation could be at least in part to the relatively small age of materials or less 
pilody penetration and pith taken from clones. The results indicated that PP was generally reliable as an indirect measure of wood basic density. The correlations between pilodyn and MoE were significantly and negative. However, the relationship between pilodyn and MoE does not seem to be documented. And further research is needed to clarify in further. The correlations between pilodyn and heartwood density were slightly positive to strongly positively, lower than the correlations between pilodyn and other wood properties because of the short length of steel needle.

\begin{tabular}{cccc}
\hline Clone number & Mean value of PP $(\mathrm{mm})$ & wood basic density $\left(\mathrm{g} . \mathrm{cm}^{-3}\right)$ & MoE $(\mathrm{GPa})$ \\
\hline 16 & 9.44 & 0.4395 & 6.48 \\
4 & 10.03 & 0.4913 & 7.42 \\
12 & 10.28 & 0.4638 & 7.53 \\
2 & 10.66 & 0.4145 & 4.93 \\
15 & 10.81 & 0.4384 & 6.14 \\
19 & 11.03 & 0.4302 & 6.31 \\
8 & 11.15 & 0.362 & 3.94 \\
20 & 11.41 & 0.4236 & 5.76 \\
6 & 11.44 & 0.4295 & 5.25 \\
18 & 11.47 & 0.4371 & 5.85 \\
21 & 11.47 & 0.4262 & 5.84 \\
10 & 11.63 & 0.4627 & 6.33 \\
1 & 12 & 0.4614 & 5.88 \\
3 & 12.22 & 0.4237 & 5.52 \\
14 & 12.69 & 0.3938 & 5.48 \\
9 & 12.97 & 0.4106 & 5.32 \\
22 & 13.09 & 0.4172 & 5.65 \\
17 & 13.5 & 0.4266 & 5.92 \\
7 & 14.03 & 0.4164 & 5.47 \\
11 & 14.94 & 0.3924 & 4.45 \\
13 & 15.34 & 0.3899 & 4.35 \\
5 & 15.41 & 0.3514 & 4.29 \\
\hline
\end{tabular}

Variance analysis of pilodyn

Table 2. The mean value of Pilodyn penetration and wood properties

\begin{tabular}{ccccccccccc}
\hline Treatment & \multicolumn{4}{c}{ PP over the bark } & \multicolumn{4}{c}{ PP with bark removal } \\
\hline Index & East & West & South & North & Mean & East & Wes & South & North & Mean \\
Mean PP $(\mathrm{mm})$ & 14.50 & 14.99 & 14.59 & 14.62 & 14.67 & 12.04 & 12.33 & 12.15 & 12.02 & 12.14 \\
C V $(\%)$ & 10.42 & 11.83 & 9.15 & 10.94 & 10.41 & 14.40 & 14.45 & 13.40 & 14.06 & 13.57 \\
\hline
\end{tabular}

Table 3 . The mean value and variation coefficient of pilodyn penetration on four directions

\begin{tabular}{cccc}
\hline Source & DF & F Value & Pr $\geq F$ \\
\hline Treatment & 1 & 16.47 & $<0.0001$ \\
Directions & 6 & 21.13 & $<0.0001$ \\
Clones & 21 & 8.10 & $<0.0001$ \\
\hline
\end{tabular}

The correlations between pilodyn and wood properties

Table 4. Variance analysis of pilodyn 


\begin{tabular}{ccccc}
\hline Directions & Wood properties & Regression equation & $\mathrm{R}^{2}$ & $\mathrm{R}$ \\
\hline \multirow{5}{*}{ East } & MoE & $\mathrm{y}=0.0341 \mathrm{x}^{2}-1.3743 \mathrm{x}+18.331$ & 0.365 & $-0.604^{* *}$ \\
& Basic density & $\mathrm{y}=0.0003 \mathrm{x}^{2}-0.0189 \mathrm{x}+0.6422$ & 0.281 & $-0.530^{*}$ \\
& Outer wood density & $\mathrm{y}=0.0007 \mathrm{x}^{2}-0.0356 \mathrm{x}+0.8051$ & 0.417 & $-0.646^{* *}$ \\
& Heartwood density & $\mathrm{y}=-0.0003 \mathrm{x}^{2}+0.0008 \mathrm{x}+0.4794$ & 0.188 & $-0.433^{*}$ \\
& MoE & $\mathrm{y}=-0.0037 \mathrm{x}^{2}-0.1913 \mathrm{x}+9.3565$ & 0.374 & $-0.611^{* *}$ \\
& Basic density & $\mathrm{y}=-2 \mathrm{E}-05 \mathrm{x}^{2}-0.0103 \mathrm{x}+0.581$ & 0.363 & $-0.603^{* *}$ \\
& Outer wood density & $\mathrm{y}=0.0009 \mathrm{x}^{2}-0.0409 \mathrm{x}+0.8485$ & 0.482 & $-0.695^{* *}$ \\
& Heartwood density & $\mathrm{y}=-0.0005 \mathrm{x}^{2}+0.0076 \mathrm{x}+0.4308$ & 0.274 & $-0.523^{*}$ \\
& MoE & $\mathrm{y}=0.05 \mathrm{x}^{2}-1.9367 \mathrm{x}+23.169$ & 0.424 & $-0.651^{* *}$ \\
& Basic density & $\mathrm{y}=0.0019 \mathrm{x}^{2}-0.0735 \mathrm{x}+1.0769$ & 0.395 & $-0.629^{* *}$ \\
& Outer wood density & $\mathrm{y}=0.0031 \mathrm{x}^{2}-0.1139 \mathrm{x}+1.4198$ & 0.521 & $-0.722^{* *}$ \\
& Heartwood density & $\mathrm{y}=0.0011 \mathrm{x}^{2}-0.0459 \mathrm{x}+0.8543$ & 0.289 & $-0.538^{* *}$ \\
& MoE & $\mathrm{y}=-0.0105 \mathrm{x}^{2}-0.0191 \mathrm{x}+8.1845$ & 0.357 & $-0.597^{* *}$ \\
& Basic density & $\mathrm{y}=-0.0003 \mathrm{x}^{2}-0.0042 \mathrm{x}+0.5399$ & 0.357 & $-0.598^{* *}$ \\
& Outer wood density & $\mathrm{y}=0.0014 \mathrm{x}^{2}-0.0579 \mathrm{x}+0.9693$ & 0.464 & $-0.681^{* *}$ \\
& Heartwood density & $\mathrm{y}=-0.0012 \mathrm{x}^{2}+0.0255 \mathrm{x}+0.3069$ & 0.284 & $-0.533^{*}$ \\
& MoE & $\mathrm{y}=0.0187 \mathrm{x}^{2}-0.9296 \mathrm{x}+15.216$ & 0.389 & $-0.624^{* *}$ \\
& Basic density & $\mathrm{y}=0.0006 \mathrm{x}^{2}-0.0313 \mathrm{x}+0.7468$ & 0.359 & $-0.599^{* *}$ \\
& Mean value & $\mathrm{y}=0.0022 \mathrm{x}^{2}-0.0823 \mathrm{x}+1.1665$ & 0.493 & $-0.702^{* *}$ \\
& Outer wood density & $\mathrm{y}=-0.0003 \mathrm{x}^{2}-7 \mathrm{E}-05 \mathrm{x}+0.4975$ & 0.262 & $-0.511^{*}$ \\
\hline & Heartwood density & &
\end{tabular}

Table 5. Regression analysis of wood properties (y) to pilodyn penetration ( $\mathrm{x}$ ) over the bark on four directions

\begin{tabular}{ccccc}
\hline Directions & Wood properties & regression equation & $\mathrm{R}^{2}$ & $\mathrm{R}$ \\
\hline \multirow{5}{*}{ East } & MoE & $\mathrm{y}=0.0429 \mathrm{x}^{2}-1.3872 \mathrm{x}+15.992$ & 0.431 & $-0.656^{* *}$ \\
& Basic density & $\mathrm{y}=9 \mathrm{E}-05 \mathrm{x}^{2}-0.0133 \mathrm{x}+0.5688$ & 0.357 & $-0.598^{* *}$ \\
& Outer wood density & $\mathrm{y}=0.0006 \mathrm{x}^{2}-0.0304 \mathrm{x}+0.7061$ & 0.529 & $-0.727^{* *}$ \\
& Heartwood density & $\mathrm{y}=-0.0005 \mathrm{x}^{2}+0.0031 \mathrm{x}+0.4548$ & 0.235 & $-0.484^{*}$ \\
& MoE & $\mathrm{y}=0.0082 \mathrm{x}^{2}-0.5428 \mathrm{x}+11.063$ & 0.431 & $-0.656^{* *}$ \\
& Basic density & $\mathrm{y}=1 \mathrm{E}-05 \mathrm{x}^{2}-0.0117 \mathrm{x}+0.5661$ & 0.414 & $-0.644^{* *}$ \\
& Outer wood density & $\mathrm{y}=0.0008 \mathrm{x}^{2}-0.0367 \mathrm{x}+0.7538$ & 0.530 & $-0.728^{* *}$ \\
& Heartwood density & $\mathrm{y}=-0.0005 \mathrm{x}^{2}+0.0033 \mathrm{x}+0.4582$ & 0.313 & $-0.560^{* *}$ \\
& MoE & $\mathrm{y}=-0.0063 \mathrm{x}^{2}-0.171 \mathrm{x}+8.6605$ & 0.365 & $-0.604^{* *}$ \\
& Basic density & $\mathrm{y}=-0.0016 \mathrm{x}^{2}+0.0291 \mathrm{x}+0.3081$ & 0.356 & $-0.596^{* *}$ \\
& Outer wood density & $\mathrm{y}=0.0002 \mathrm{x}^{2}-0.0204 \mathrm{x}+0.6545$ & 0.528 & $-0.727^{* *}$ \\
& Heartwood density & $\mathrm{y}=-0.0027 \mathrm{x}^{2}+0.0589 \mathrm{x}+0.1055$ & 0.263 & $-0.513^{*}$ \\
& MoE & $\mathrm{y}=0.0054 \mathrm{x}^{2}-0.4438 \mathrm{x}+10.18$ & 0.344 & $-0.587^{* *}$ \\
& Basic density & $\mathrm{y}=-0.0007 \mathrm{x}^{2}+0.0061 \mathrm{x}+0.453$ & 0.375 & $-0.613^{* *}$ \\
& North & $\mathrm{y}=0.0012 \mathrm{x}^{2}-0.045 \mathrm{x}+0.7988$ & 0.541 & $-0.736^{* *}$ \\
& Outer wood density & $\mathrm{y}=-0.0018 \mathrm{x}^{2}+0.0353 \mathrm{x}+0.2603$ & 0.282 & $-0.531^{*}$ \\
& Heartwood density & $\mathrm{y}=0.0079 \mathrm{x}^{2}-0.5492 \mathrm{x}+11.117$ & 0.418 & $-0.646^{* *}$ \\
& MoE & $\mathrm{y}=-0.0008 \mathrm{x}^{2}+0.0084 \mathrm{x}+0.4432$ & 0.404 & $-0.635^{* *}$ \\
& Basic density & $\mathrm{y}=0.0006 \mathrm{x}^{2}-0.0326 \mathrm{x}+0.7318$ & 0.569 & $-0.755^{* *}$ \\
& Outer wood density & $\mathrm{y}=-0.0018 \mathrm{x}^{2}+0.0341 \mathrm{x}+0.2696$ & 0.295 & $-0.543^{* *}$ \\
\hline \multirow{5}{*}{ Mean value } & Heartwood density & &
\end{tabular}

Table 6. Regression analysis of wood properties (y) to pilodyn penetration( $\mathrm{x}$ ) with bark removal on four directions

\section{Conclusion}

In the present study, the effectiveness of pilodyn for assessing wood properties of eucalyptus clones in standing trees was discussed. The results obtained are as follows: 
1. The mean value of Pilodyn penetration, wood basic density and MoE ranged from 9.44

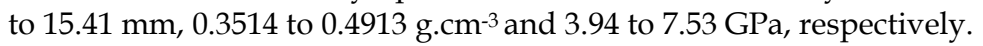

2. There were significant differences between pilodyn penetration of different treatment, different directions and different clones. The coefficient of variation ranged from $9.15 \%$ to $11.83 \%$ for Pilodyn penetration over the bark and ranged from $13.40 \%$ to $14.45 \%$ for Pilodyn penetration with bark removal.

3. The correlations between pilodyn and wood properties were generally strongly negative, and the coefficients ranged from -0.433 to -0.755 . The results indicated that wood basic density and MoE can be predicted by using pilodyn. Results from this study also tend to confirm those of Cown (1981) who concluded that Pilodyn is not an accurate equipment for measurement, but it does provide an effective and efficient means of estimating wood properties.

\section{Acknowledgements}

We thank Huang Hongjian, Tan Peitao and Hu Yang from Xinhui Forest Bureau for their assistance. Comments from K. Harding, D. Pegg, Dr. Zeng Jie and an anonymous reviewer are appreciated.

\section{References}

Chapola Gbj. 1994. Assessment of some wood properties of eucalyptus species grown in Malawi using pilodyn method. Discovery and Innovation. 6(1):98-109

Chauhan S.S., Walker J.C.F. 2006. Variation in acoustic and density with age, and their interrelationships in radiation pine. Forest Ecology and Management. 229:388-394

Cown, D.J.. 1981. Use of the pilodyn wood tester for estimating wood density in standing trees - in fluce of site and tree age. World Forestry Conference.

Cown D J . 1978. Comparison of the Pilodyn and torsiometer methods for the rapid assessment of wood density in living trees. N ZJ For Sci, :384 - 3911

Dean, G.H. 1995. Objectives for wood fibre quality and uniformity. In: pott, B.M., Borralho, N.M.G., Reid, J. B., Cromer, R. N., Tibbits, W.N. and Raymond, C.A. (eds). Eucalypts plantations: improving fibre yield and quality. CR-IUFRO Conf., Hobart, 19-24 Feb. 483 pp.

Ikemori Y. K., Martins F. C. G. and Zobel, B. J.. 1986 The impact of accelerated breeding on 31 wood Properties. In proceedings of the 18th IUFRO World 32 Conference Division 5: Forest products. Ljubljana, Yugoslavia. p.358-368

Ishiguri, F., Matsui, R., Lizuka, K., Yokota, S. and Yoshizawa, N. 2008. Prediction of the mechanical properties of lumber by stress-wave velocity and Pilodyn penetration of 36-year-old Japanese larch trees. Oiginal Arbelten · Originals. 66: 275-280

Greaves, B.L., Borralho, N.M.G, Raymond, C.A. and Farrington, A. 1996. Use of a pilodyn for the indirect selection of basic density in Eucalyptus nitens.Canadian Journal of Forest Research. 26(9):1643-1650

Hansen C. P. 2000. Application of the Pilodyn in forest tree improvement. DFSC Series of Technical Notes. TN55. Danida Forest Seed Centre, Humlebaek, Denmark.

Hansen J.K., Roulund H. 1996. Genetic parameters for spiral grain, stem form, pilodyn and growth in 13 years old clones of Sitka Spruce (Picea sitchensis (Bong.) Carr.). Silva Genetica. 46 (2-3):107-113 
Jacques D., Marchal M. and Curnel y. 2004. Relative efficiency of alternative methods to evaluate wood stiffness in the frame of hybrid larch (Larix $\times$ eurolepis Henry) clonal selection. Ann. For. Sci. 61. pp:35-43

Knowles R. Leith, Hansen Lars W., Wedding Adele, Downes Geoffrey. 2004. Evaluation of non-destructive methods for assessing stiffness of Douglas fir trees. New Zealand Journal of Forestry Science. 34(1):87-101

Kube P., Raymond C. 2002. Selection strategies for genetic improvement of basic density in Eucalyptus nitens. Tcchnical repoet 92.

Knowles, L. R., Hansen, L.W., Wendding, A. and Downes, G.. 2004. Evaluation of nondestructive methods for assessing stiffness of douglas fir trees. New Zealand Journal of Forestry Science. 34(1)::87-101

Laurence, R Schimleck, Anthony J Michell, Carolyn A Raymond, Allie Muneri. 1999. Estimation of basic density of Eucalyotus globulus using near-infrared spectroscopy. Canadian Journal of Forest Research. Feb. 29:194-202

$\mathrm{Lu}, \mathrm{Z}$., Xu, J., Bai J. and Zhou,W.. 2000. A study on wood property variation between Eucalyptus tereticornis and Eucalyptus camalduensis. Forest Research. 13(4):370-376

Luo, J. 2003 Variation in growth and wood density of Eucalyptus urophylla. In turnbull, J. W.(Ed.) "Eucalypts in Asia" ACIAR proceedingsNo. 111. Zhanjiang, Guangdong, China.

Macdonald A.C., Borralho N.M.G.and Potts B.M. 1997. Genetic variation for growth and wood density in eucalyptus globulus ssp.globulus in Tasmania (Australia). Silva Genetica. 46 (4):236-241

Kien N. D., Jansson G., Harwood C., Almqvist C., Thinh H. H. 2008. Genetic variation in wood basic density and pilodyn penetration and their relationships with growth, stem straightness and branch size for eucalyptus urophylla S.T.Blake in Northern Vietnam. New Zealand Journal of Forestry Science. 38 (1):160-175

Pliura A., Zhang S. Y., Mackay J. and Bousquet. 2007. Genotipic variation in wood density and growth traits of poplar hybrids at four clonal trials. Forest Ecology and Management. 2007 238: 92-106

Qi S. 2007. Applied Eucalypt cultivation in China. Beijing: China Forestry Publishing House

Raymond, C.A. and MacDonald, A.C. 1998. Where to shoot your pilodyn: within tree variation in basic density in plantation eucalyptus globulus and E. nitens in Tasmania. New Forests. 15: 205-221.

Tappi.1989. Basic density and moisture content of pulpwood. TAPPI no. T258 om-98

Wang X., Ross R. J., Mcclellan M., Barbour R. J., Erickson J. R., Forsman J.W. and Mcgin G. 36 D. 2000. Strength and stiffness assessment of standing trees using a 37 nondestructive stress wave technique. Res. Pap. FPL-RP-585. U.S. Department of 38 Agriculture, Forest Service, Forest Products Laboratory, Madison, WI.

Wei X., N.M.G.Borralho. 1997. Genetic control of basic density and bark thickness and their relationships with growth traits of Eucalyptus urophylla in south east China. Silvae Genetica. 46(4):245-250

Yin Y., Wang L., Jiang X.. 2008. Use of Pilodyn tester for estimating basic density in standing trees of hardwood plantation. Journal of Beijing Forestry University 30 ( 4 ): 7-11

Zhu J., Wang J., Zhang S., Zhang J., Sun X., Liang B.. 2008. Wood property estimation and selection of populus tomentosa. Scientia Silvae Science. 44(7): 23-28

Zhu J., Wang J., Zhang S., Zhang J., Sun X., Liang B., Zhao K. 2009. Using the pilodyn to assess wood traits of standing trees Laix kaempfri. Forest Research. 22(1): 75-79 


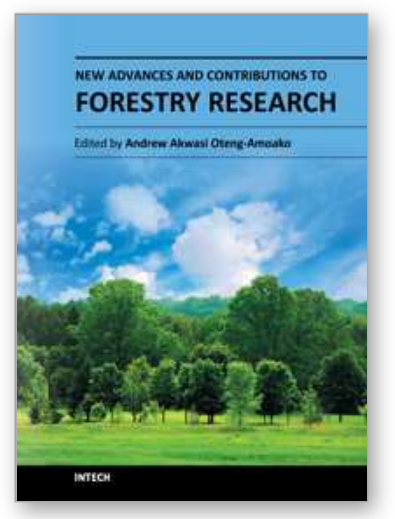

\author{
New Advances and Contributions to Forestry Research \\ Edited by Dr. Dr. Andrew A. Oteng-Amoako
}

ISBN 978-953-51-0529-9

Hard cover, 256 pages

Publisher InTech

Published online 27, April, 2012

Published in print edition April, 2012

New Advances and Contributions to Forestry Research consists of 14 chapters divided into three sections and is authored by 48 researchers from 16 countries and all five continents. Section Whither the Use of Forest Resources, authored by 16 researchers, describes negative and positive practices in forestry. Forest is a complex habitat for man, animals, insects and micro-organisms and their activities may impact positively or negatively on the forest. This complex relationship is explained in the section Forest and Organisms Interactions, consisting of contributions made by six researchers. Development of tree plantations has been man's response to forest degradation and deforestation caused by human, animals and natural disasters. Plantations of beech, spruce, Eucalyptus and other species are described in the last section, Amelioration of Dwindling Forest Resources Through Plantation Development, a section consisting of five papers authored by 20 researchers. New Advances and Contributions to Forestry Research will appeal to forest scientists, researchers and allied professionals. It will be of interest to those who care about forest and who subscribe to the adage that the last tree dies with the last man on our planet. I recommend it to you; enjoy reading it, save the forest and save life!

\title{
How to reference
}

In order to correctly reference this scholarly work, feel free to copy and paste the following:

Wu Shijun, Xu Jianmin, Li Guangyou, Risto Vuokko, Lu Zhaohua, Li Baoqi and Wang Wei (2012). Use of the Pilodyn for Assessing Wood Properties in Standing Trees of Eucalyptus Clones, New Advances and Contributions to Forestry Research, Dr. Dr. Andrew A. Oteng-Amoako (Ed.), ISBN: 978-953-51-0529-9, InTech, Available from: http://www.intechopen.com/books/new-advances-and-contributions-to-forestryresearch/use-of-the-pilodyn-for-assessing-wood-properties-in-standing-trees-of-eucalyptus-clones

\section{INTECH}

open science | open minds

\author{
InTech Europe \\ University Campus STeP Ri \\ Slavka Krautzeka 83/A \\ 51000 Rijeka, Croatia \\ Phone: +385 (51) 770447 \\ Fax: +385 (51) 686166 \\ www.intechopen.com
}

\author{
InTech China \\ Unit 405, Office Block, Hotel Equatorial Shanghai \\ No.65, Yan An Road (West), Shanghai, 200040, China \\ 中国上海市延安西路65号上海国际贵都大饭店办公楼 405 单元 \\ Phone: +86-21-62489820 \\ Fax: +86-21-62489821
}


(C) 2012 The Author(s). Licensee IntechOpen. This is an open access article distributed under the terms of the Creative Commons Attribution 3.0 License, which permits unrestricted use, distribution, and reproduction in any medium, provided the original work is properly cited. 